
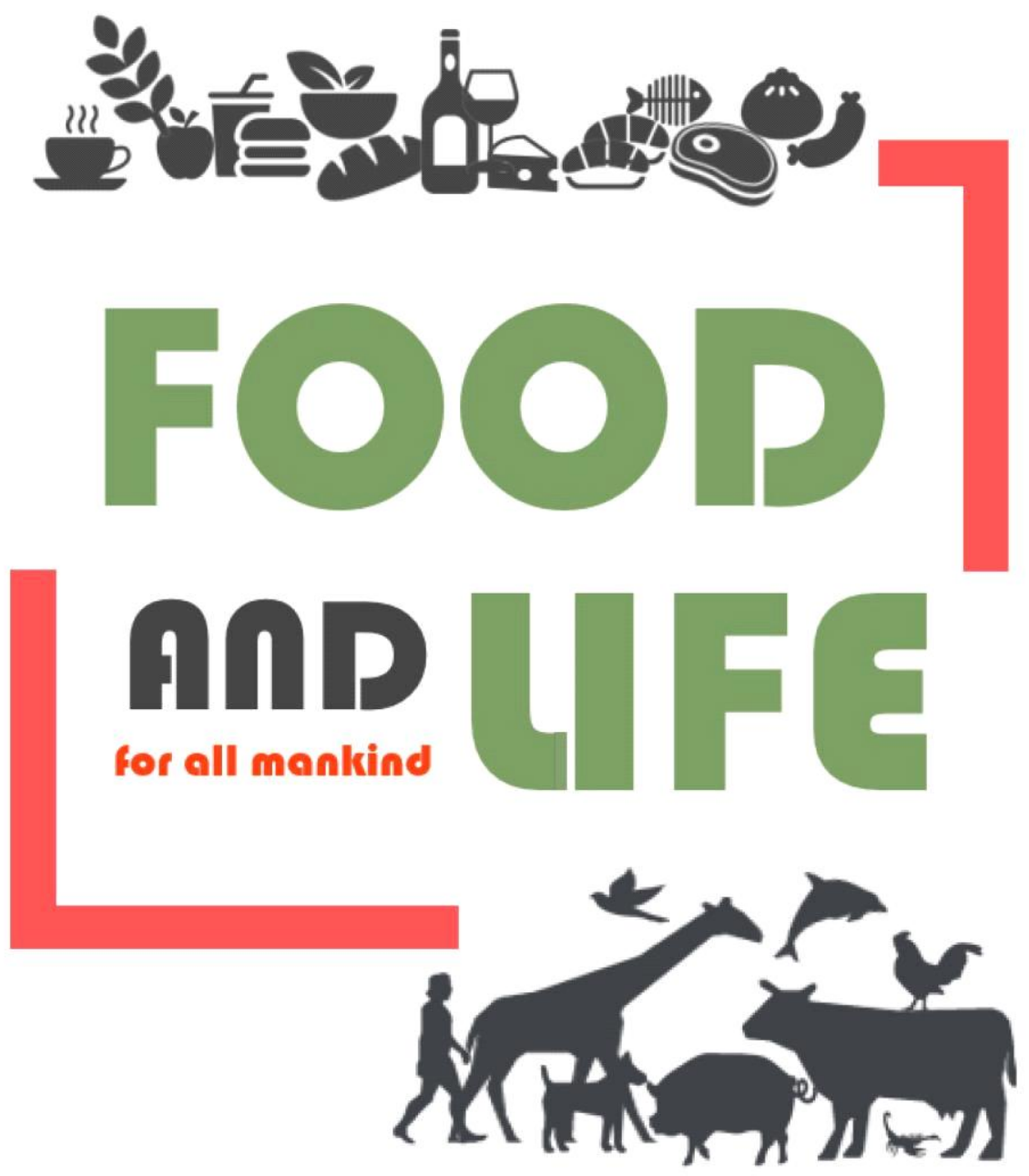

The Food and Life has published all type articles such as research articles, review articles, survey articles, research note, short communication or editorial since 2020. It covers the all scientific and technological aspects of food and life science.

\title{
https://www.foodnlife.org
}




\title{
유청 단백질을 이용한 마이야르 공액체 기반 나노 에멀젼 전달체의 기능적 특성
}

이세희 ${ }^{1,2}$, 이원재 ${ }^{1,2, *}$

1경상국립대학교 동물생명과학과

2경상국립대학교 농업생명과학연구원

\section{Functional property of Maillard conjugate-based nano emulsion delivery system using whey protein: a mini review}

\author{
Sehee Lee ${ }^{1,2}$, Won-Jae Lee 1,2,* \\ ${ }^{1}$ Department of Animal Bioscience, Gyeongsang National University, Jinju 52828, Korea \\ ${ }^{2}$ Institute of Agriculture and Life Science, Gyeongsang National University, Jinju 52828, Korea
}

\begin{abstract}
Numerous hydrophobic bioactive compounds are susceptible to decomposition and contain low bioavailability because of their poor water solubility and chemical stability during food processing and storage, and gastrointestinal digestion. The use of Maillard conjugate-based nanoemulsion delivery system using whey protein can be a promising way to enhance the chemical stability and bioavailability. It is attributed to the enhanced functional properties of Maillard conjugate, such as thermal stability, emulsifying property, and antioxidant property. In this review, technological approaches to enhance the physicochemical functionality of whey protein-based Maillard conjugate will be discussed.
\end{abstract}

Keywords: nano emulsion delivery system, milk protein, Maillard conjugate, functional property

서 론

나노 에멀젼 전달체(nano emulsion delivery system)는 1-200 $\mathrm{nm}$ 크기를 지닌 아주 작은 크기의 전달체로 정의할 수 있으며, 유식품 제조 공정 및 저장, 소화 기간 동안 생리 활성 화합물 (bioactive compound)을 보호하고 이용성을 극대화할 수 있다 (Fathi et al., 2012; Ron et al., 2010). 소수성(hydrophobic) 생리 활성 화합물은 건강 기능성 향상에 중요한 역할을 하지만, 식 품 가공 및 저장조건, 위장 소화 과정 중 낮은 용해도 및 물리 화학적 안정성 저하로 인해 생체 이용률(bioavailability)이 낮아 유식품 적용 시 한계가 있다(Bryant and McClements, 1998). 이러한 소수성 생리 활성 화합물의 유식품 적용 시 발생 가능 한 문제점들을 해결하기 위해 이용되는 나노 에멀젼 전달체는 매우 작은 입자크기로 인해 표면적이 넓기 때문에 소화관 내 용해도가 증가하고, 위장 체류 시간을 연장하여 생리 활성 화 합물의 생체 이용률을 향상시킬 수 있으며, 식품 가공 및 저장 조건 하에서의 생리 활성 화합물의 안정성을 향상시킬 수 있다
(Banerjee et al., 2016; Han et al., 2008; Kohane, 2007).

유단백질(milk protein)은 대략 $80 \%$ 케이신(casein)과 $20 \%$ 유 청 단백질(whey protein)으로 구성되어 있다. 그중 유청 단백질은 $\alpha$-lactalbumin, $\beta$-lactoglobulin, bovine serum albumin, lactoferrin, immunoglobulin으로 구성되어 있으며, 필수아미노산을 다량 함유하고 있어 영양학적 가치가 뛰어나다(Livney, 2010; Sun and Gunasekaran, 2009). 유청 단백질은 낮은 독성, 생체 적합성 및 생 분해성이며, 겔화(gelation) 능력을 지니고 있다. 또한 낮은 수용해 도로 인해 유식품 적용에 문제점을 지니고 있는 docosahexaenoic $\operatorname{acid}(\mathrm{DHA})$, eicosapentaenoic acid(EPA) 등과 같은 소수성 생리 활성 화합물에 대한 우수한 결합능력으로 인해 나노 전달체 제 조 시 surface coating material로 이용되어 왔다(Adjonu et al., 2014; Ha et al., 2019; Shafaei et al., 2017). 그러나 유청 단백 질은 제조공정 요인(예: 온도, $\mathrm{pH})$ 에서 구조적 특성 변화로 인 한 유화 능력 저하로 나노 에멀젼 적용 시 문제점을 지니고 있 다(Capanni et al., 2004; $\mathrm{Li}$ and $\mathrm{Gu}, 2011$; Luo et al., 2011; Yi

"Corresponding author : Won-Jae Lee. Department of Animal Bioscience (Institute of Agriculture and Life Science), Gyeongsang National University, Jinju 52828, Korea. Tel: +82-55-772-1884, Fax: +82-55-772-1889, E-mail: wjleewisc@gnu.ac.kr

This is an Open-Access article distributed under the terms of the Creative Commons Attribution Non-Commercial License which permits unrestricted non-commercial use, distribution, and reproduction in any medium, provided the original work is properly cited (http://creativecommons.org/licenses/by-nc/4.0/). 
et al., 2006). 본 리뷰에서는 이러한 유청 단백질을 나노 에멀젼 전달체의 coating material로 이용 시 발생 가능한 문제점들을 최소화하기 위해 유청 단백질을 이용한 마이야르 반응(Maillard reaction)을 기반으로 생성되는 공액체(conjugate)를 이용하여 유 청 단백질의 물리화학적 기능성(physicochemical functionality) 을 향상시켜 궁극적으로 나노 전달체의 생리 활성 화합물 이용 성을 증가시키는 최신 기술 트렌드에 대해 논하고자 한다.

\section{마이야르 공액체}

마이야르 반응은 식품을 저장하거나 가열하는 동안 단백 질과 다당류 사이에서 발생하는 비효소적 갈변 반응(nonenzymatic browning)이며, 마이야르 반응의 초기 단계에서는 $\mathrm{N}$-glycosylamines을 형성하는 아미노산/펩티드/단백질의 유리 아미노기와 환원당의 카르보닐기 사이의 축합(condensation)이 진 행되면서 불안정한 N-glycosylamines은 Amadori rearrangement을 거쳐 ketosamine을 형성한다. 앞서 생성된 ketosamine는 reductone과 diacetyl, pyruvaldehyde 및 기타 단쇄 가수 분해 생성물 들을 형성한다. 마지막 단계에서 reductone 및 가수분해 산물, Strecker 분해 산물은 aldol과 aldehyde-amine 축합 반응을 거쳐 궁극적으로 갈색 지소 고분자인 melanoidin을 생성한다(Hodge, 1953; Peng et al., 2011). 마이야르 반응 결과 생성된 melanoidin 은 향상된 건강 기능성 특히 항산화, 항균 기능을 지니고 있다. 그러나 마이야르 반응의 최종 단계가 오래 지속되면 당뇨병 및 알츠하이머와 같은 질병 유발 요인이 될 수 있기 때문에 마이 야르 반응을 고압(400 MPa)에서 수행하거나 $\mathrm{pH}$ 를 8.0보다 낮 게 설정하여 질병 유발 요인 형성을 억제할 수 있다(de Oliveira et al., 2016; Moreno et al., 2003; Silván et al., 2011).

마이야르 반응을 통해 생성된 마이야르 공액체(Maillard conjugate)는 단백질과 다당류의 공유결합으로 형성되며, 기존 단백질보다 우수한 용해도 및 유화 능력, 항산화 특성으로 인 해 전달체의 coating material로 사용 시 기능적 특성(functional properties) 향상을 통해 다양한 긍정적인 효과를 기대할
수 있다(Nooshkam and Madadlou, 2016a; Nooshkam and Madadlou, 2016b; Vhangani and Van Wyk, 2013; Vhangani and Van Wyk, 2016). 마이야르 공액체의 여러 기능적 특성은 공액체 제조 공정 요인인 마이야르 반응 시간과 열처리 온도 및 $\mathrm{pH}$, 원료, 단백질과 다당류의 초기 비율 등에 영향을 받는다 (Table 1). Wang 등(2020)의 유청 단백질(whey protein isolate, $\mathrm{WPI}$ 과 이눌린 공액체의 연구에서 $\mathrm{pH}$ 가 3.0 에서 7.0으로 증가 함에 따라 공액체의 유화 특성이 유의적으로 증가하였으며, 특 히 유화 안정성 실험에서 $\mathrm{pH}$ 가 증가함에 따라 큰 증가가 나타 났다. 또한 마이야르 공액체 제조 시 마이야르 반응 시간이 2시 간에서 6시간으로 증가함에 따라 항산화 특성인 ABTS [2,2'azino-bis(3-ethylbenzothiazoline-6-sulfonic acid)] radical 소거 활성이 유의적으로 증가하였다.

\section{마이야르 공액체의 기능적 특성}

\section{열 안정성}

유청 단백질은 고온 열처리 공정[예: 일반적인 상업용 발효 유 열처리 $\left(85^{\circ} \mathrm{C} / 30\right.$ 분, $95^{\circ} \mathrm{C} / 10$ 분, 상업용 우유 멸균( $138^{\circ} \mathrm{C} / 4$ 초)] 에서 고온으로 인한 구조적 변화 및 침전으로 인해 유청 단백 질의 기능적 손실을 초래할 수 있다(de Oliveira et al., 2016; Rinaldi et al., 2014; Wang et al., 2006). 유청 단백질과 환원당 간의 마이야르 반응 결과, 형성된 마이야르 공액체는 열처리 공정 시 유청 단백질 변성으로 인한 단백질 간의 intermolecular hydrophobic interaction을 감소시켜 열처리로 인한 유청 단백 질의 구조적 변화를 억제할 수 있다(Sasahara et al., 2003). 소 수성 부분의 결합을 방해하여 단백질의 구조를 보호하며 또한 마이야르 공액체 형성에 음이온성 다당류를 이용할 경우, 입체 장애(steric hindrance) 및 정전기적 반발(electrostatic repulsion) 로 인해 결합된 단백질의 열 안정성을 증가시켜 열처리시 단백 질의 응집을 방지할 수 있다(Liu et al., 2019). Jiménez-Castaño 등(2007)의 유청 단백질인 $\beta$-lactoglobulin( $\beta$ - Lg)과 환원당인

Table 1. Enhanced functional properties of Maillard conjugates according to parameters

\begin{tabular}{|c|c|c|c|c|c|c|c|}
\hline \multicolumn{6}{|c|}{ Parameters } & \multirow{2}{*}{ Functional property } & \multirow{2}{*}{ Reference } \\
\hline Protein $(P)$ & Carbohydrate (C) & Ratio P:C & Temp $\left({ }^{\circ} \mathrm{C}\right)$ & Time(h) & $\mathrm{pH}$ & & \\
\hline \multirow[t]{4}{*}{$\begin{array}{l}\text { Whey protein } \\
\text { isolate }\end{array}$} & Inulin & $\begin{array}{c}1: 1,2: 1,4: 1 \\
5: 1,6: 1\end{array}$ & $\begin{array}{c}70,75 \\
80\end{array}$ & $\begin{array}{l}12,24 \\
48,72\end{array}$ & 7.0 & $\begin{array}{l}\text { Thermal stability } \\
\text { emulsifying properties }\end{array}$ & $\begin{array}{l}\text { He and Vardhanabhuti } \\
(2021)\end{array}$ \\
\hline & Gum acacia & $1: 2$ & 60 & $\begin{array}{l}24,72, \\
120,168\end{array}$ & - & $\begin{array}{l}\text { Thermal stability } \\
\text { emulsifying properties }\end{array}$ & Chen et al. (2019) \\
\hline & Inulin & $1: 1$ & 70 & $2,4,6$ & 9.0 & $\begin{array}{l}\text { Emulsifying properties } \\
\text { oxidative stability }\end{array}$ & Wang et al. (2020) \\
\hline & Flaxseed gum & $3: 1$ & 60 & $22,48,72$ & $.2-7.4$ & $\begin{array}{l}\text { Thermal stability } \\
\text { emulsifying properties }\end{array}$ & Dong et al. (2020) \\
\hline Whey protein & Inulin & $\begin{array}{c}3: 1,2: 1,1: 1 \\
1: 2,1: 3\end{array}$ & 60 & 120 & 7.0 & Oxidative stability & Wang et al. (2019) \\
\hline
\end{tabular}


dextran 마이야르 공액체를 이용한 열 안정성 연구에서 $\beta-\operatorname{Lg}$ 만 을 이용하였을 경우와 비교하여 $\beta-\mathrm{Lg} / \mathrm{dextran}$ 마이야르 공액체 의 $\mathrm{pH} 5.0$ 및 7.0에서 열 안정성이 유의적으로 더 높았다. 또한 분자량이 다른 dextran에 대한 $\beta-\mathrm{Lg} / \mathrm{dextran}$ 마이야르 공액체의 열 안정성 연구에서는 dextran이 $20 \mathrm{kDa}$ 인 $\beta-\mathrm{Lg} /$ dextran 마이 야르 공액체의 열 안정성은 dextran이 $10 \mathrm{kDa}$ 인 공액체보다 유 의적으로 높았는데, 이러한 결과는 고분자 탄수화물의 입체 반발이 저분자 탄수화물의 입체 반발에 비해 높기 때문이다 (O'Mahony et al., 2017).

\section{유화특성}

마이야르 반응을 이용한 마이야르 공액체 형성은 단백질 의 유화 특성(emulsifying properties)을 향상시키는 것으로 알 려졌다(Feng et al., 2016). 마이야르 공액체의 단백질 부분은 $\mathrm{O} / \mathrm{W}$ 에멀젼(oil in water emulsion)의 oil droplet 표면에 빠르게 흡착되고, 공액체의 환원당 부분은 입체 장애(steric hindrance) 및 정전기적 반발력(electrostatic repulsion)을 통해 oil droplet 의 응집을 억제할 수 있어 결과적으로 유화 특성을 향상시킬 수 있다(Gumus et al., 2016). Wang 등(2020)의 native WPI 및 WPI-Inulin 마이야르 공액체를 이용한 유화 활성 지수(EAI; emulsifying activity index) 및 유화 안정성 지수(emulsion stability index, ESI) 실험에서 WPI-Inulin 마이야르 공액체의 유화 활성 지수는 native WPI의 유화 활성 지수보다 유의적으 로 상당히 높았다. 이러한 유화 활성 증가는 WPI-Inulin 마이야 르 공액체가 당화 반응을 통해 사슬 형태가 확장되고, 표면 구 조가 느슨하게 되어 결과적으로 $\mathrm{O} / \mathrm{W}$ 에멀젼의 기름-물 계면 (oil-water interface)에서 흡착(adsorption)을 더 빨리 촉진했기 때문입니다(Mu et al., 2006; Xu and Yao, 2009). 또한 WPIInulin 마이야르 공액체의 유화 안정성 지수(ESI)는 $\mathrm{pH}$ 3.0-7.0 범위에서 native WPI보다 유의적으로 높았는데, 이러한 향상된 유화 안정성은 WPI-Inulin 마이야르 공액체가 native WPI와 비 교하여 상대적으로 높은 정전기적 반발력을 지니고 있어 보다 안정적으로 에멀젼 droplet 표면에 흡착하고, 에멀젼 형성 동안 droplet 응집(flocculation) 속도를 느리게 하기 때문이다(Consoli et al., 2018; Yang et al., 2018). 이와 같이 유청 단백질 유래 마 이야르 공액체의 우수한 유화 특성은 에멀젼 형태의 전달체에서 천연 유화제로의 역할을 할 수 있음을 의미한다.

\section{항산화적 특성}

마이야르 공액체의 항산화 특성은 유식품 저장 기간 동안 소 수성 생리 활성 화합물(예: $\mathrm{DHA}, \mathrm{EPA}$ 등)의 산화적 산패 (oxidative rancidity) 관련 문제를 최소화할 수 있다(Nooshkama et al., 2020). 마이야르 반응을 이용하여 단백질과 환원당으로 제조된 마이야르 공액체의 항산화 특성 연구에서 마이야르 반
응으로 생성되는 Amadori 유래 성분, reductone 및 melanoidin 과 같은 마이야르 반응 생성물(Maillard reaction production: $\mathrm{MRP}$ )에서 우수한 항산화 효과가 보고되었으며, 마이야르 공액 체의 항산화 활성은 분자량, $\mathrm{pH}$, 온도, 반응시간 등을 포함한 많은 요인의 영향을 받는다(Franzke and Iwainsky, 1954; Nooshkam et al., 2019). 예를 들면 마이야르 반응 생성물인 melanoidin은 분자량에 따라 항산화 활성이 달라지는데, 상대 적으로 긴 마이야르 반응시간에서 생성된 고분자 melanoidin은 저분자 melanoidin보다 항산화 활성이 높다고 보고되었다 (Wang et al., 2011). 이러한 마이야르 반응 생성물의 항산화 특 성은 자동산화(autoxidation) 과정 중 radical chain reaction을 종결하기 위한 hydroxyl pyrrole 그룹의 전자 전달활성(electron transfer activity) 기능, 금속이온 킬레이트화, $\mathrm{H}_{2} \mathrm{O}_{2}$ 파괴 효과 및 활성 산소 포집 기능을 통해 향상된다고 알려져 있다 (Nooshkam and Madadlou, 2016; Wang et al., 2013). 마이야르 공액체는 건강 기능성 불포화 지방산인 DHA 등을 함유한 기 능성 유제품의 산화 반응을 억제하는 잠재적 항산화제로 사용 가능하다(Giroux et al., 2010; Nooshkam et al., 2020).

\section{마이야르 기반 전달체의 소화적 효과}

소화 과정 동안 생리 활성 화합물의 생체 이용률을 증진시키 기 위해 위장 내 조건에서 생리 활성 화합물의 물리화학적 안 정성 및 생체 접근성 향상, 분해 감소 및 흡수 개선 등이 필요 하다(Chen et al., 2018). 단백질과 환원당 유래 마이야르 공액 체를 이용하여 제조된 에멀젼 전달체는 천연 단백질에 의해 안 정화된 에멀젼 전달체와 비교하여 위장 내 소화과정(예: $\mathrm{pH}$ 1.0-3.0 및 펩신에 의한 단백질 분해) 동안 생리 활성 화합물에 보다 높은 protection effect를 제공하는 것으로 알려졌다 (Gumus et al., 2016; Lesmes and McClements, 2012; Xu et al., 2014; Zhong et al., 2019). 마이야르 공액체는 O/W 에멀젼 전 달체의 oil droplet 주위에 두꺼운 계면안정층(interfacial layer) 을 형성하고, 이렇게 형성된 계면안정층이 에멀젼 droplet과 펩 신 간의 상호 작용을 억제하고, 결과적으로 위장 내 소화과정에 서 생리 활성 화합물을 보호한다(Davidov-Pardo et al., 2015). 케이신-말토덱스트린(casein-maltodextrin) 마이야르 공액체를 이용한 전달체의 위장 소화 연구 결과, 말토덱스트린 공액체의 계면 안정층으로 인한 barrier effect로 인해 전달체 내 포집된 소수성 생리 활성 화합물이 pepsinolysis로부터 보호되었다 (Markman and Livney, 2012). 또한 소화 과정 동안 생리 활성 화합물의 생체 이용률을 증진시키는 요인에는 마이야르 공액 체의 barrier effect뿐만 아니라, 마이야르 공액체를 이용하여 제 조된 에멀젼 전달체의 droplet size가 전달체에 의해 포집된 생 리 활성 화합물의 생체 이용률에 영향을 미친다. Fig. 1은 WPI 와 Inulin 마이야르 공액체를 이용하여 제조된 $\mathrm{O} / \mathrm{W}$ 에멀젼 전달 

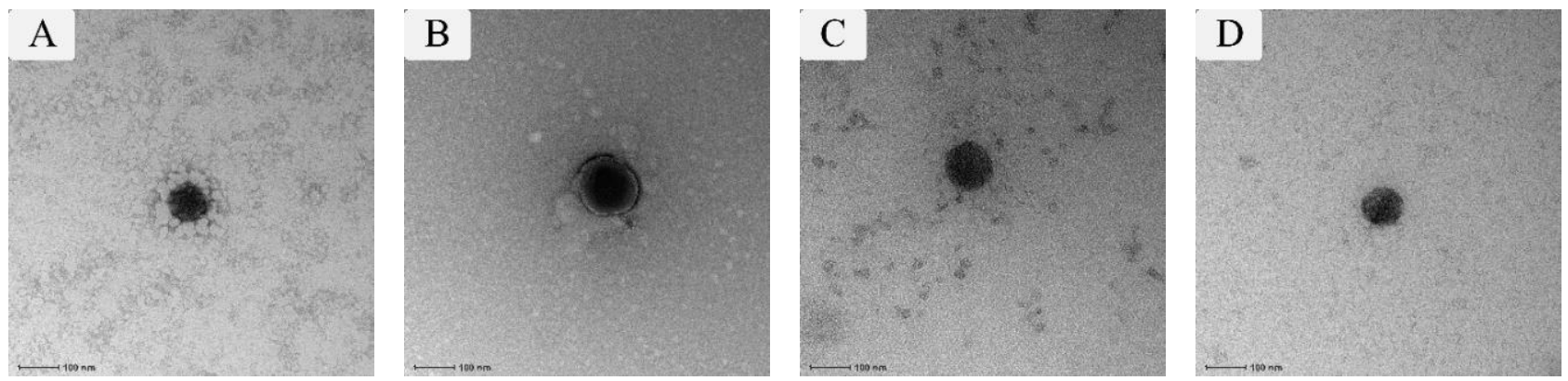

Fig. 1. TEM images of Maillard conjugate-based nanoemulsion delivery system. WPI (1\%)/Inulin (1\%) mixtures at $\mathrm{pH} 7.0$ (A, B) and $\mathrm{pH} 8.4(\mathrm{C}, \mathrm{D})$ were heated at $60^{\circ} \mathrm{C}(\mathrm{A}, \mathrm{C})$ and $70^{\circ} \mathrm{C}(\mathrm{B}, \mathrm{D})$ for 12 hours. Scale bar=100 nm. TEM, transmission electron microscope; WPI, whey protein isolate.

체를 투과전자현미경(transmission electron microscope, TEM)으 로 관찰한 결과이며, droplet size가 대략 $100 \mathrm{~nm}$ 인 것을 확인 할 수 있다. 나노미터 크기의 에멀젼 전달체는 증가된 표면적으 로 인해 소장의 mucosal adhesion과 장내 상피세포와의 상호작 용을 증진시킬 수 있으며(Banerjee et al., 2016; Yao et al., 2015). 그 결과 포집된 생리 활성 화합물의 생체 이용률을 증가시킬 것 으로 예상된다(Acosta, 2009; Fathi et al., 2012; Ha et al., 2015).

\section{결 론}

생리 활성 화합물은 건강 기능성 향상에 중요한 역할을 하지 만, 식품 가공 및 저장조건, 위장 소화 과정 중 낮은 용해도 및 물리화학적 안정성 저하로 인해 생체 이용률(bioavailability)이 낮아 유식품 적용 시 한계가 있다. 유청 단백질과 환원당을 반 응시킨 마이야르 공액체는 우수한 열 안정성, 유화 능력, 및 항 산화 특성을 지니고 있어 나노 에멀젼 전달체의 coating material으로 이용 시 식품 가공 및 저장조건, 위장 소화 과정 중 소수성(hydrophobic) 생리 활성 화합물의 생체 이용률을 증 진시킬 수 있는 효과적인 기능성 식품 소재이다.

\section{Conflicts of Interest}

The authors declare no potential conflict of interest.

\section{Acknowledgments}

This work was supported by Basic Science Research Program (NRF-2020R1F1A107397512) through the National Research Foundation of Korea (NRF) funded by the Ministry of Education, Korea.

\section{Ethics Approval}

This article does not require IRB/IACUC approval because there are no human and animal participants

\section{Author Contributions}

Conceptualization: Lee WJ.

Writing-original draft: Lee S.

Writing-review\&editing: Lee S, Lee WJ.

\section{Author Information}

See-he Lee (Graduate Student, Gyeongsang National University) https://orcid.org/0000-0002-1132-4663

Won-Jae Lee (Professor, Gyeongsang National University) https://orcid.org/0000-0001-8391-6863

\section{References}

Acosta E. 2009. Bioavailability of nanoparticles in nutrient and nutraceutical delivery. Curr Opin Colloid Interface Sci 14:3-15.

Adjonu R, Doran G, Torley P, Agboola S. 2014. Whey protein peptides as components of nanoemulsions: a review of emulsifying and biological functionalities. J Food Eng 122:15-27.

Banerjee A, Qi J, Gogoi R, Wong J, Mitragotri S. 2016. Role of nanoparticle size, shape and surface chemistry in oral drug delivery. J Control Release 238:176-185.

Bryant CM, McClements DJ. 1998. Molecular basis of protein functionality with special consideration of cold-set gels derived from heat-denatured whey. Trends Food Sci Technol 9:143-151.

Capanni C, Taddei N, Gabrielli S, Messori L, Orioli P, Chiti F, Stefani M, Ramponi G. 2004. Investigation of the effects of copper ions on protein aggregation using a model system. Cell Mol Life Sci 61:982-991.

Chen W, Lv R, Wang W, Ma X, Muhammad AI, Guo M, Ye 
X, Liu D. 2019. Time effect on structural and functional properties of whey protein isolate-gum acacia conjugates prepared via Maillard reaction. J Sci Food Agric 99:4801-4807.

Chen X, McClements DJ, Zhu Y, Zou L, Li Z, Liu W, Cheng C, Gao H, Liu C. 2018. Gastrointestinal fate of fluid and gelled nutraceutical emulsions: impact on proteolysis, lipolysis, and quercetin bioaccessibility. J Agric Food Chem 66:9087-9096.

Consoli L, Dias RAO, Rabelo RS, Furtado GF, Sussulini A, Cunha RL, Hubinger MD. 2018. Sodium caseinate-corn starch hydrolysates conjugates obtained through the Maillard reaction as stabilizing agents in resveratrol-loaded emulsions. Food Hydrocoll 84:458-472.

Davidov-Pardo G, Pérez-Ciordia S, Marín-Arroyo MR, McClements DJ. 2015. Improving resveratrol bioaccessibility using biopolymer nanoparticles and complexes: impact of proteincarbohydrate Maillard conjugation. J Agric Food Chem 63: 3915-3923.

de Oliveira FC, Coimbra JSR, de Oliveira EB, Zuñiga ADG, Rojas EEG. 2016. Food protein-polysaccharide conjugates obtained via the Maillard reaction: a review. Crit Rev Food Sci Nutr 56:1108-1125.

Dong X, Du S, Deng Q, Tang H, Yang C, Wei F, Chen H, Quek SY, Zhou A, Liu L. 2020. Study on the antioxidant activity and emulsifying properties of flaxseed gum-whey protein isolate conjugates prepared by Maillard reaction. Int J Biol Macromol 153:1157-1164.

Fathi M, Mozafari MR, Mohebbi M. 2012. Nanoencapsulation of food ingredients using lipid based delivery systems. Trends Food Sci Technol 23:13-27.

Feng J, Wu S, Wang H, Liu S. 2016. Improved bioavailability of curcumin in ovalbumin-dextran nanogels prepared by Maillard reaction. J Funct Foods 27:55-68.

Franzke C, Iwainsky H. 1954. Zurantioxidativen wirksamkeit der melanoidine. Dtsch Lebensmitt Rundsch 50:251-254.

Giroux HJ, Houde J, Britten M. 2010. Use of heated milk protein-sugar blends as antioxidant in dairy beverages enriched with linseed oil. LWT-Food Sci Technol 43: 1373-1378

Gumus CE, Davidov-Pardo G, McClements DJ. 2016. Luteinenriched emulsion-based delivery systems: impact of Maillard conjugation on physicochemical stability and gastrointestinal fate. Food Hydrocoll 60:38-49.
Ha HK, Kim JW, Lee MR, Jun W, Lee WJ. 2015. Cellular uptake and cytotoxicity of $\beta$-lactoglobulin nanoparticles: the effects of particle size and surface charge. AsianAustralas J Anim Sci 28:420-427.

Ha HK, Rankin SA, Lee MR, Lee WJ. 2019. Development and characterization of whey protein-based nano-delivery systems: a review. Molecules 24:3254.

Han F, Li S, Yin R, Liu H, Xu L. 2008. Effect of surfactants on the formation and characterization of a new type of colloidal drug delivery system: nanostructured lipid carriers. Colloids Surf A Physicochem Eng Asp 315:210-216.

He Y, Vardhanabhuti B. 2021. Improved heat stability of whey protein isolate by glycation with inulin. Dairy 2:135-147.

Hodge JE. 1953. Dehydrated foods, chemistry of browning reactions in model systems. J Agric Food Chem 1:928-943.

Jiménez-Castaño L, Villamiel M, López-Fandiño R. 2007. Glycosylation of individual whey proteins by Maillard reaction using dextran of different molecular mass. Food Hydrocoll 21:433-443.

Kohane DS. 2007. Microparticles and nanoparticles for drug delivery. Biotechnol Bioeng 96:203-209.

Lesmes U, McClements DJ. 2012. Controlling lipid digestibility: response of lipid droplets coated by $\beta$-lactoglobulin-dextran Maillard conjugates to simulated gastrointestinal conditions. Food Hydrocoll 26:221-230.

Li Z, Gu L. 2011. Effects of mass ratio, pH, temperature, and reaction time on fabrication of partially purified pomegranate ellagitannin-gelatin nanoparticles. J Agric Food Chem 59:4225-4231

Liu J, Fang C, Xu X, Su Q, Zhao P, Ding Y. 2019. Physicochemical and functional properties of silver carp myosin glycated with konjac oligo-glucomannan: effects of deacetylation. Food Chem 291:223-230.

Livney YD. 2010. Milk proteins as vehicles for bioactives. Curr Opin Colloid Interface Sci 15:73-83.

Luo Y, Zhang B, Whent M, Yu L, Wang Q. 2011. Preparation and characterization of zein/chitosan complex for encapsulation of $a$-tocopherol, and its in vitro controlled release study. Colloids Surf B Biointerfaces 85:145-152.

Markman G, Livney YD. 2012. Maillard-conjugate based coreshell co-assemblies for nanoencapsulation of hydrophobic nutraceuticals in clear beverages. Food Funct 3:262-270.

Moreno FJ, Molina E, Olano A, López-Fandiño R. 2003. High-pressure effects on Maillard reaction between glucose 
and lysine. J Agric Food Chem 51:394-400.

Mu M, Pan X, Yao P, Jiang M. 2006. Acidic solution properties of $\beta$-casein-graft-dextran copolymer prepared through Maillard reaction. J Colloid Interface Sci 301:98-106.

Nooshkam M, Falah F, Zareie Z, Tabatabaei Yazdi F, Shahidi F, Mortazavi SA. 2019. Antioxidant potential and antimicrobial activity of chitosan-inulin conjugates obtained through the Maillard reaction. Food Sci Biotechnol 28:1861-1869.

Nooshkam M, Madadlou A. 2016a. Microwave-assisted isomerisation of lactose to lactulose and Maillard conjugation of lactulose and lactose with whey proteins and peptides. Food Chem 200:1-9.

Nooshkam M, Madadlou A. 2016b. Maillard conjugation of lactulose with potentially bioactive peptides. Food Chem 192:831-836.

Nooshkam M, Varidi M, Verma DK. 2020. Functional and biological properties of Maillard conjugates and their potential application in medical and food: A review. Food Res Int 131:109003.

O’Mahony JA, Drapala KP, Mulcahy EM, Mulvihill DM. 2017. Controlled glycation of milk proteins and peptides: functional properties. Int Dairy J 67:16-34.

Peng X, Ma J, Chen F, Wang M. 2011. Naturally occurring inhibitors against the formation of advanced glycation end-products. Food Funct 2:289-301.

Rinaldi L, Gauthier SF, Britten M, Turgeon SL. 2014. In vitro gastrointestinal digestion of liquid and semi-liquid dairy matrixes. LWT-Food Sci Technol 57:99-105.

Ron N, Zimet P, Bargarum J, Livney YD. 2010. Beta-lactoglobulin-polysaccharide complexes as nanovehicles for hydrophobic nutraceuticals in non-fat foods and clear beverages. Int Dairy J 20:686-693.

Sasahara K, McPhie P, Minton AP. 2003. Effect of dextran on protein stability and conformation attributed to macromolecular crowding. J Mol Biol 326:1227-1237.

Shafaei Z, Ghalandari B, Vaseghi A, Divsalar A, Haertlé T, Saboury AA, Sawyer L. 2017. $\beta$-Lactoglobulin: an efficient nanocarrier for advanced delivery systems. Nanomedicine13: 1685-1692.

Silván JM, Assar SH, Srey C, Dolores del Castillo M, Ames JM. 2011. Control of the Maillard reaction by ferulic acid. Food Chem 128:208-213.

Sun C, Gunasekaran S. 2009. Effects of protein concentration and oil-phase volume fraction on the stability and rheology of menhaden oil-in-water emulsions stabilized by whey protein isolate with xanthan gum. Food Hydrocoll 23:165-174.

Vhangani LN, Van Wyk J. 2013. Antioxidant activity of Maillard reaction products (MRPs) derived from fructoselysine and ribose-lysine model systems. Food Chem 137:92-98.

Vhangani LN, Van Wyk J. 2016. Antioxidant activity of Maillard reaction products (MRPs) in a lipid-rich model system. Food Chem 208:301-308.

Wang C, Wang H, Sun X, Sun Y, Guo M. 2019. Heat-induced interactions between whey protein and inulin and changes in physicochemical and antioxidative properties of the complexes. Int J Mol Sci 20:4089.

Wang HY, Qian H, Yao WR. 2011. Melanoidins produced by the Maillard reaction: structure and biological activity. Food Chem 128:573-584.

Wang Q, Tolkach A, Kulozik U. 2006. Quantitative assessment of thermal denaturation of bovine $\alpha$-lactalbumin via low-intensity ultrasound, HPLC, and DSC. J Agric Food Chem 54:6501-6506.

Wang WQ, Bao YH, Chen Y. 2013. Characteristics and antioxidant activity of water-soluble Maillard reaction products from interactions in a whey protein isolate and sugars system. Food Chem 139:355-361.

Wang WD, Li C, Bin Z, Huang Q, You LJ, Chen C, Fu X, Liu RH. 2020. Physicochemical properties and bioactivity of whey protein isolate-inulin conjugates obtained by Maillard reaction. Int $\mathrm{J}$ Biol Macromol 150:326-335.

Win KY, Feng SS. 2005. Effects of particle size and surface coating on cellular uptake of polymeric nanoparticles for oral delivery of anticancer drugs. Biomaterials 26:27132722.

Xu D, Yuan F, Gao Y, Panya A, McClements DJ, Decker EA. 2014. Influence of whey protein-beet pectin conjugate on the properties and digestibility of $\beta$-carotene emulsion during in vitro digestion. Food Chem 156:374-379.

Xu K, Yao P. 2009. Stable oil-in-water emulsions prepared from soy protein-dextran conjugates. Langmuir 25:97149720.

Yang J, Mao L, Yang W, Sun C, Dai L, Gao Y. 2018. Evaluation of non-covalent ternary aggregates of lactoferrin, high methylated pectin, EGCG in stabilizing $\beta$-carotene emulsions. Food Chem 240:1063-1071. 
Yao M, He L, McClements DJ, Xiao H. 2015. Uptake of gold nanoparticles by intestinal epithelial cells: impact of particle size on their absorption, accumulation, and toxicity. J Agric Food Chem 63:8044-8049.

Yi K, Cheng G, Xing F. 2006. Gelatin/tannin complex nanospheres via molecular assembly. J Appl Polym Sci 101:3125-3130.

Zhong L, Ma N, Wu Y, Zhao L, Ma G, Pei F, Hu Q. 2019.
Gastrointestinal fate and antioxidation of $\beta$-carotene emulsion prepared by oat protein isolate-Pleurotus ostreatus $\beta$-glucan conjugate. Carbohydr Polym 221:10-20.

(c) Copyright. Korean Society for Food Science of Animal Resources. Date Received Jul. 15, 2021 Date Revised Aug. 25, 2021 Date Accepted Aug. 26, 2021 